\title{
Influence of Morphine and Naloxone on Endothelin and its Receptors in Newborn Piglet Brain Vascular Endothelial Cells: Clinical Implications in Neonatal Care
}

\author{
RICHARD VAN WOERKOM, KAY D.A. BEHARRY, HOUCHANG D. MODANLOU, \\ JACQUELINE PARKER, VIGNA RAJAN, YASIR AKMAL, AND JACOB V. ARANDA \\ Division of Neonatal-Perinatal Medicine, Department of Pediatrics, University of California, Irvine, \\ Orange, California 92868, U.S.A. [R.V.W., K.D.A.B., H.D.M., V.R.], Perinatal Department at Women's \\ Hospital, Miller Children's Hospital [R.V.W., V.R.], Research Administration [Y.A.], Long Beach \\ Memorial Medical Center, Long Beach, California 90806, U.S.A., Wayne State University, Detroit, \\ Michigan 48201, U.S.A. [J.P., J.V.A.]
}

\begin{abstract}
The present study examines the hypothesis that morphine exposure alters newborn brain vascular endothelial cell production of endothelin (ET)-1, as well as the mRNA expression of its receptors. Newborn piglet vascular endothelial cells were treated with morphine (100 ng/mL media), naloxone $(100 \mathrm{ng} / \mathrm{mL}$ media), or drug-free media (control) for 6, 24, 48, and $96 \mathrm{~h}$. Media was analyzed for ET-1 and big ET-1 levels and the cells were assessed for $\mathrm{ET}_{\mathrm{A}}$ and $\mathrm{ET}_{\mathrm{B}}$ receptor mRNA expression. Morphine exposure progressively increased ET-1 production from 6 to $96 \mathrm{~h}$ with concurrent reductions in big ET-1 levels starting at $24 \mathrm{~h}$ to almost undetectable levels by $96 \mathrm{~h}$. Whereas $\mathrm{ET}_{\mathrm{A}}$ receptor mRNA expression increased 2-fold at $6 \mathrm{~h}$ and 4-fold at $96 \mathrm{~h}, \mathrm{ET}_{\mathrm{B}}$ receptor mRNA expression remained unchanged. Naloxone exposure caused significant decreases in ET-1 levels, whereas an opposite effect was noted in big ET-1 levels, which increased
\end{abstract}

\section{ABSTRACT}

from 6 through $96 \mathrm{~h}$. Naloxone caused a progressive decrease in $\mathrm{ET}_{\mathrm{A}}$ receptor mRNA expression at $6 \mathrm{~h}$ through $96 \mathrm{~h}$ and a 2 -fold increase in $\mathrm{ET}_{\mathrm{B}}$ receptor mRNA expression at 48 and $96 \mathrm{~h}$. Increased ET-1 and its receptors in response to morphine may suggest altered cerebrovascular perfusion and brain metabolism in the immature piglet brain. (Pediatr Res 55: 147-151, 2004)

$\quad$ Abbreviations
ECE, endothelin converting enzyme
ET-1, endothelin-1
EtBr, ethidium bromide
IVH, intraventricular hemorrhage
NO, nitric oxide
PVL, periventricular leukomalacia
TFA, trifluoroacetic acid

Intermittent and/or continuous infusions of morphine are often used for analgesia and sedation of infants in the neonatal intensive care unit. In the newborn piglet, continuous infusion of morphine results in increased systemic and sagittal sinus vein ET-1 levels (1). In vitro, ET-1 is involved in cerebral pial artery vasoconstriction, and therefore may be involved in the regulation of cerebral blood flow (2). ET-1 is a potent vasoconstrictive peptide that binds with high affinity to the endo-

Received August 20, 2002; accepted July 10, 2003

Correspondence: Houchang D. Modanlou, M.D., Director, Neonatal-Perinatal Medicine Fellowship Training Program, University of California, Irvine Medical Center, Division of Neonatology, Building 2, Route 81, 101 The City Drive South, Orange, California 92868, U.S.A.; e-mail: modanlou@uci.edu

Supported by grants from the Long Beach Memorial Medical Center Foundation, Long Beach, California, and the Medical Research Council of Canada, Ottawa, Canada.

Presented, in part, at the 1999 Society for Pediatric Research Meeting in Boston, Massachusetts.

DOI: 10.1203/01.PDR.0000100756.32861.60 thelin receptor $\mathrm{ET}_{\mathrm{A}}$, which mediates vasoconstriction by activating the phospholipase $\mathrm{C}$ /protein kinase $\mathrm{C}$ cascade (3), by decreasing smooth muscle sensitivity to NO (4), and possibly by increasing cytosolic free calcium levels (5) and superoxide anion production (6). The endothelin receptor $\mathrm{ET}_{\mathrm{B}}$ has a lower affinity for ET-1 and mediates vascular relaxation through a mechanism coupled to endothelial production of nitric oxide (7), although some vasoconstrictor activity of $\mathrm{ET}_{\mathrm{B}}$ has also been shown $(8,9)$. "Big ET" is a precursor to endothelin with almost no vasoconstrictor activity (10); ET-1 is formed when big ET-1 is cleaved by ECE (11). Published data have shown poor correlation between systemic ET levels and tissue levels of its production (12).

We have previously shown that morphine infusion in newborn piglets increases ET-1 levels, up-regulates ET $_{\mathrm{A}}$ mRNA expression, and down-regulates $\mathrm{ET}_{\mathrm{B}}$ mRNA expression as measured in systemic and sagittal sinus venous blood and 
brainstem tissue homogenates (1). We therefore hypothesized that exposure of cultured brain vascular endothelial cells to morphine would result in increased levels of ET-1 and increased $\mathrm{ET}_{\mathrm{A}}$ mRNA expression. We further hypothesized that exposure of the same cells to the morphine antagonist naloxone would result in opposite effects. This study aimed to examine and compare the biochemical and molecular responses of the endothelin system in cultured newborn piglet brain vascular endothelial cells to morphine and naloxone in an attempt to elucidate possible cerebrovascular effects of a drug commonly used in human newborns.

\section{METHODS}

All experiments were conducted according to the guidelines of the Institutional Review Board and Institutional Animal Care and Use Committee of McGill University, Montreal, Canada. Animals were treated according to the guidelines outlined by the National Research Council Guide for the Care and Use of Laboratory Animals. Euthanasia of the animals was conducted according to the guidelines of the American Veterinary Medical Association.

Animal and cell preparation. The brains of newborn Yorkshire piglets (1-3 d old, $1-2 \mathrm{~kg}$ ) were perfused with $100 \mathrm{~mL}$ normal saline and harvested. Microvessels were extracted from the porcine brains using HBSS and Ficoll. These microvessels were plated on T25 culture flasks in endothelial cell-specific media with low serum environment $(5 \%)$ containing growth factors, cytokines, and supplements (Clonetics Corporation, San Diego, CA, U.S.A.). Endothelial cells were verified by staining with factor VIII Von Willebrand factor. Cells were passaged after $3 \mathrm{wk}$ ( $80 \%$ confluence) to T80 flasks. Cells were exposed to morphine, naloxone, or saline once cultures reached $80 \%$ confluence. Media were collected at desired time points as described in the following protocol.

Experimental protocol. Cultured cells were divided in three groups: 1) a control group in drug-free saline media $(10 \mathrm{~mL})$; 2) a morphine group in $100 \mathrm{ng} / \mathrm{mL}$ morphine sulfate media (10 $\mathrm{mL}$ ); and 3) a naloxone group in $100 \mathrm{ng} / \mathrm{mL}$ naloxone media $(10 \mathrm{~mL})$. Each group of cells was exposed to their respective media for time increments as follows: time $0(n=6), 6 \mathrm{~h}(n=$ $6), 24 \mathrm{~h}(n=6), 48 \mathrm{~h}(n=6)$, and $96 \mathrm{~h}(n=6)$.

Extraction of ET-1 and big ET-1. Media samples $(500 \mu \mathrm{L})$ were collected in ice-cold polypropylene tubes containing a $500 \mu \mathrm{L}$ solution of EDTA $(1 \mathrm{mg} / \mathrm{mL})$, and aprotinin $(500$ $\mathrm{KIU} / \mathrm{mL}$ ). The samples were extracted by addition of $1.0 \mathrm{~mL}$ TFA (1\%) in $99 \%$ distilled water and centrifuged at $6000 \times g$ for $20 \mathrm{~min}$ at $4^{\circ} \mathrm{C}$. The supernatant was loaded onto a C-18 Sep column that was previously equilibrated by washing with $100 \%$ acetonitrile followed by $1 \%$ TFA. The peptides were eluted slowly with $60 \%$ acetonitrile, $1 \%$ TFA, and 39\% distilled water. The eluant was collected in a clean polypropylene tube, evaporated to dryness, and reconstituted in assay buffer.

Assay procedure. ET-1 and big ET-1 levels were determined using enzyme immunoassay kits purchased from Peninsula Laboratories (Belmont, CA, U.S.A.). Each kit consisted of a polystyrene 96-well immunoplate precoated with peptide antibody. Aliquots of the reconstituted samples were loaded in duplicate onto the wells and the assay was carried out according to the manufacturer's protocol. Absorbance was measured at $450 \mathrm{~nm}$ in an automated plate reader (EAR $400 \mathrm{AT}$, SLT Labinstruments $\mathrm{GmbH}$, Salzburg, Austria). The absorbance was correlated with ET-1 or big ET-1 concentrations in the standards to generate a standard curve that ranged from 0 to $1000 \mathrm{ng} / \mathrm{mL}$. The total assay time was $4.5 \mathrm{~h}$.

Total RNA isolation. Total RNA of the sample was isolated by homogenization $\left(1 \mathrm{~mL} / 1 \times 10^{6}\right.$ cells $)$ in TriZol reagent (Invitrogen, Carlsbad, CA, U.S.A.). Chloroform $(0.2 \mathrm{~mL})$ was added and the tube shaken vigorously by hand. The samples were incubated for 2-3 $\mathrm{min}$ at room temperature then centrifuged at $14,000 \mathrm{rpm}$ for $15 \mathrm{~min}$ at $4^{\circ} \mathrm{C}$. The aqueous phase was transferred to a new tube and $0.5 \mathrm{~mL}$ isopropanol added. The samples were vortexed and incubated for $10 \mathrm{~min}$ at room temperature, then centrifuged for $10 \mathrm{~min}$ at $14,000 \mathrm{rpm}$ at $4^{\circ} \mathrm{C}$. The isopropanol was decanted and the pellet washed with $1 \mathrm{~mL}$ of $80 \%$ ethanol. After centrifugation for $5 \mathrm{~min}$ at $8000 \mathrm{rpm}$ the pellet was dissolved in $50 \mu \mathrm{L}$ of RNase free water and incubated at $55^{\circ} \mathrm{C}$ for $10 \mathrm{~min}$ in a water bath. At this point the purity of the RNA was assessed by the ratio of absorbance at $260 \mathrm{~nm}$ and $280 \mathrm{~nm}$. The total RNA concentration was estimated by spectrophotometric measurements at $260 \mathrm{~nm}$ assuming $40 \mu \mathrm{g}$ of RNA per milliliter equals one absorbance unit. The integrity of the RNA was determined by gel electrophoresis in $1 \%$ agarose gel stained with EtBr. The total RNA yield was diluted in RNase-free water to $1 \mu \mathrm{g} / \mu \mathrm{L}$ total RNA for all samples.

Reverse transcriptase (RT)-PCR. Two micrograms of total RNA was reverse transcribed to cDNA using $100 \mathrm{ng}$ random hexamers in $20 \mathrm{~mL}$ solution containing $50 \mathrm{mM}$ Tris $\mathrm{HCl}, 75$ $\mathrm{mM} \mathrm{KCl}, 3 \mathrm{mM} \mathrm{MgCl}_{2}, 10 \mathrm{mM}$ DTT, $500 \mu \mathrm{M}$ each of DNTP, and 10 units MuLV reverse transcriptase (PerkinElmer Instruments, Norwalk, CT, U.S.A.) for 45 min. PCR was performed for amplification of cDNA using 1 unit AmpliTaq DNA polymerase and specific sense and anti-sense primers for $\beta$-actin, $\mathrm{ET}_{\mathrm{A}}$, and $\mathrm{ET}_{\mathrm{B}}$ (Invitrogen). The sense and antisense primer sequences for $\beta$-actin mRNA were 5'-CCT TCC TGC GCA TGG AGT CCT GG-3' and 5'-GGA GCA ATG ATC TTG ATC TTC-3', respectively. The sense and antisense primer sequences for the $\mathrm{ET}_{\mathrm{A}}$ receptor mRNA were 5'-CGC TGA TAG CCA GTC TTG-3' and 5'-CGG TTC TTG TCC ATT TCG-3', respectively. The sense and antisense primer sequences for $\mathrm{ET}_{\mathrm{B}}$ receptor mRNA were 5'-GGA CCC ATC GAG ACT AAG G-3' and 5'-AGA ATC CTG CTG AGG TGA AGG-3', respectively. PCR products were amplified over 30 cycles as follows: $45 \mathrm{~s}$ denaturing at $94^{\circ} \mathrm{C}, 45 \mathrm{~s}$ primer annealing at $61^{\circ} \mathrm{C}$, and $1 \mathrm{~min}$ extension/synthesis at $72^{\circ} \mathrm{C}$.

Densitometric scanning. Gel electrophoresis of the PCR products was performed on a $1.5 \%$ agarose gel stained with EtBr. The intensities of the bands were measured with the use of a GelDoc 1000 Darkroom Imager and Molecular Analyst software (Bio-Rad, Hercules, CA, U.S.A.). The PCR fragments were identified according to their molecular mass using a DNA mass ladder (PerkinElmer Instruments). The amount of DNA in each specimen was semi-quantitated by the integrated density of the product bands within a closed rectangle, which was then normalized to the density of the $\beta$-actin bands. Identifi- 
cation of the DNA fragments was accomplished with the use of a 100 base pair DNA ladder, which consisted of 15 blunt-ended fragments between 100 and 1500 base pairs. The data are expressed as mean $\mathrm{ET}_{\mathrm{A}}$ or $\mathrm{ET}_{\mathrm{B}} / \beta$-actin ratio $\pm \mathrm{SEM}$.

Statistical analysis. Data were analyzed using SPSS (SPSS Inc., Chicago, IL, U.S.A.) and GraphPad Prism (GraphPad Software, San Diego, CA, U.S.A.). One-way ANOVA was used to detect differences between control, morphine, and naloxone groups. Data for mRNA expression of $\mathrm{ET}_{\mathrm{A}}$ and $\mathrm{ET}_{\mathrm{B}}$ receptors are expressed as mean $\mathrm{ET}_{\mathrm{A}}$ or $\mathrm{ET}_{\mathrm{B}}$ mRNA expression over $\beta$-actin mRNA expression. Significance was determined using the Student-Newman-Keuls test, with statistical significance set at a $p$ value of 0.05 , values being expressed as mean $\pm \mathrm{SEM}$.

\section{RESULTS}

Effect of morphine and naloxone on ET-1 production. Figure 1 shows the effects of morphine and naloxone on ET-1 levels. ET-1 levels for cells exposed to morphine increased from $0.52 \pm 0.04$ at $0 \mathrm{~h}$, to $0.87 \pm 0.11$ at $6 \mathrm{~h}, 0.70 \pm 0.08$ at $24 \mathrm{~h}, 0.75 \pm 0.07$ at $48 \mathrm{~h}$, and $0.68 \pm 0.06$ at $96 \mathrm{~h}(p<0.05$ at $6 \mathrm{~h}$ and $48 \mathrm{~h}$ versus saline control). In contrast, ET-1 levels (ng/mL) for cells exposed to naloxone progressively decreased from $0.51 \pm 0.04$ at $0 \mathrm{~h}$ to $0.15 \pm 0.05$ at $6 \mathrm{~h}, 0.25 \pm 0.08$ at $24 \mathrm{~h}, 0.28 \pm 0.06$ at $48 \mathrm{~h}$, and $0.23 \pm 0.03$ at $96 \mathrm{~h}(p<0.01$ at $6 \mathrm{~h}$ and $48 \mathrm{~h}$ versus saline, $p<0.05$ at $96 \mathrm{~h}$ versus saline). ET-1 levels $(\mathrm{ng} / \mathrm{mL})$ for control cells remained unchanged from $0 \mathrm{~h}(0.51 \pm 0.04)$ through $6 \mathrm{~h}(0.58 \pm 0.11), 24 \mathrm{~h}(0.43$ $\pm 0.13), 48 \mathrm{~h}(0.55 \pm 0.04)$, and $96 \mathrm{~h}(0.51 \pm 0.08)$.

Effect of morphine and naloxone on big ET-1 production. A quite different response pattern became apparent for big ET-1 (ng/mL) production (Fig. 2). Big ET-1 levels decreased from $0.35 \pm 0.04$ at $0 \mathrm{~h}$ and $0.39 \pm 0.06$ at $6 \mathrm{~h}$ to $0.24 \pm 0.15$ at $24 \mathrm{~h}, 0.28 \pm 0.04$ at $48 \mathrm{~h}$, and $0.18 \pm 0.08$ at $96 \mathrm{~h}(p<0.01$ at $48 \mathrm{~h}$ versus saline). Conversely, big ET-1 levels $(\mathrm{ng} / \mathrm{mL})$ progressively increased in response to naloxone from $0.65 \pm$ 0.43 at $0 \mathrm{~h}$, to $1.00 \pm 0.09$ at $6 \mathrm{~h}, 1.45 \pm 0.33$ at $24 \mathrm{~h}, 1.02 \pm$ 0.10 at $48 \mathrm{~h}$, and $0.97 \pm 0.07$ at $96 \mathrm{~h}(p<0.05$ at $24 \mathrm{~h}$ and $48 \mathrm{~h}$ versus saline, $p<0.001$ at $96 \mathrm{~h}$ versus saline). Levels of big

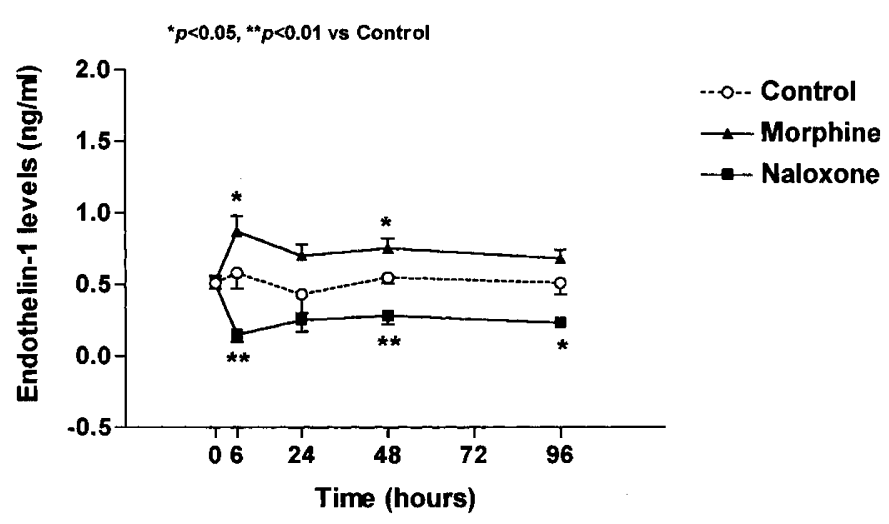

Figure 1. Time course of ET-1 production by newborn piglet brain vascular endothelial cells treated with morphine sulfate $(100 \mathrm{ng} / \mathrm{mL}$ media) and naloxone (100 ng/mL media). The control group was exposed to drug-free media. Data are expressed as mean \pm SEM.

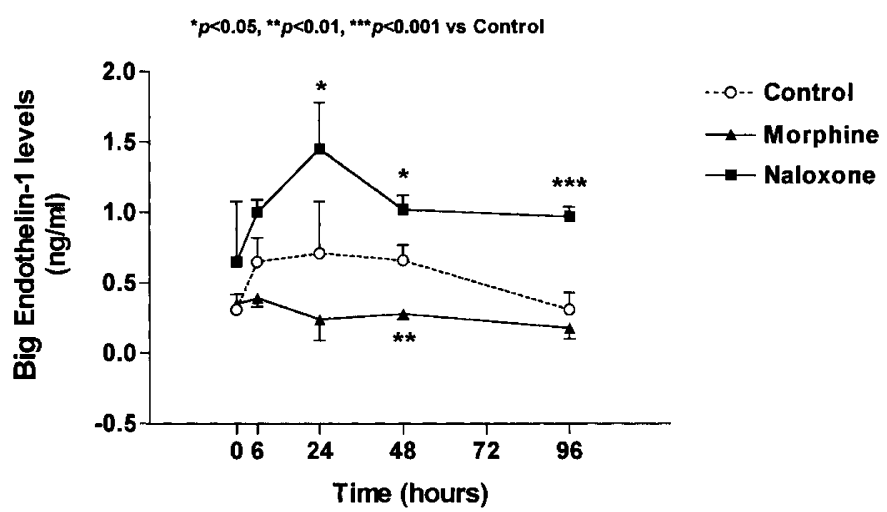

Figure 2. Time course of big ET-1 production by newborn piglet brain vascular endothelial cells treated with morphine sulfate $(100 \mathrm{ng} / \mathrm{mL}$ media $)$ and naloxone (100 ng/mL media). The control group was exposed to drug-free media. Data are expressed as mean \pm SEM.

ET-1 in the control group were $0.31 \pm 0.11$ at $0 \mathrm{~h}, 0.65 \pm 0.17$ at $6 \mathrm{~h}, 0.71 \pm 0.37$ at $24 \mathrm{~h}, 0.66 \pm 0.11$ at $48 \mathrm{~h}$, and $0.31 \pm$ 0.12 at $96 \mathrm{~h}$.

Effect of morphine and naloxone on $E T_{A} m R N A$ expression. mRNA expression of $\mathrm{ET}_{\mathrm{A}}$ increased with morphine exposure at $6 \mathrm{~h}$ (2-fold, $p<0.05), 24 \mathrm{~h}$ (3.5-fold, $p<0.05)$, $48 \mathrm{~h}$ (2-fold, $p<0.01)$, and $96 \mathrm{~h}$ (5-fold, $p<0.01)$ compared with control (Fig. 3). However, compared with control, $\mathrm{ET}_{\mathrm{A}}$ mRNA expression decreased at $6 \mathrm{~h}$ (2.5-fold, $p<0.05), 24 \mathrm{~h}$ (2-fold), 48 h (11-fold, $p<0.01)$, and 96 h (17-fold, $p<0.05$ ) in the naxolone-exposed cells.

Effect of morphine and naloxone on $E T_{B} m R N A$ expression. Figure 4 illustrates the mRNA expression of $\mathrm{ET}_{\mathrm{B}}$ in response to morphine and naloxone. Morphine treatment had no significant effect on mRNA expression of $\mathrm{ET}_{\mathrm{B}}$ by newborn piglet brain vascular endothelial cells. In contrast, naloxone exposure resulted in a 3-fold increase in $\mathrm{ET}_{\mathrm{B}}$ mRNA expression at 48 and $96 \mathrm{~h}(p<0.001)$ compared with control levels.

Figure 5 represents gels from a single sample taken from a group of six samples at each time interval, for RT-PCR amplification of newborn piglet brain vascular endothelial cell $\beta$-actin, $\mathrm{ET}_{\mathrm{A}}$ and $\mathrm{ET}_{\mathrm{B}}$ receptor mRNA expression. Lanes $1-6$ represents $0-96 \mathrm{~h}$ of incubation, respectively. This figure

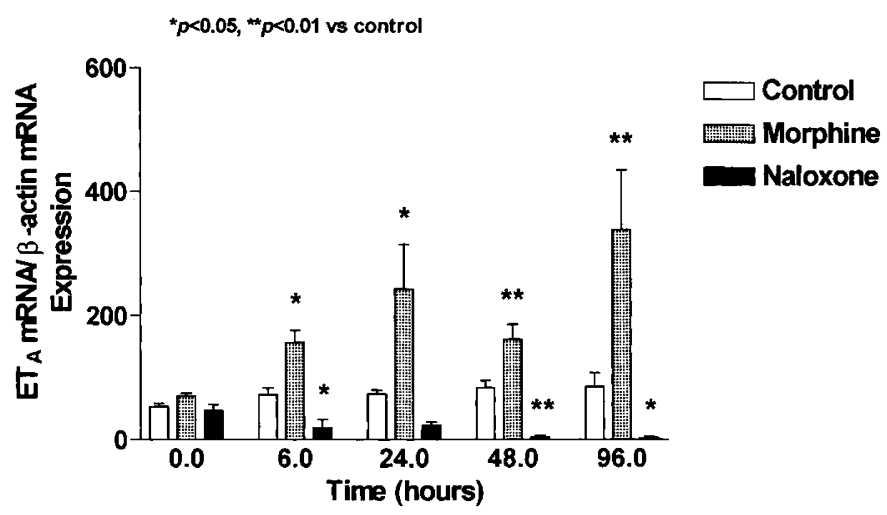

Figure 3. Response of $\mathrm{ET}_{\mathrm{A}}$ receptor to morphine and naloxone in newborn piglet brain vascular endothelial cells. The graph represents the mean ratio \pm SEM of each $\mathrm{ET}_{\mathrm{A}}$ mRNA to $\beta$-actin mRNA expression. Samples from six flasks in each group were analyzed. 


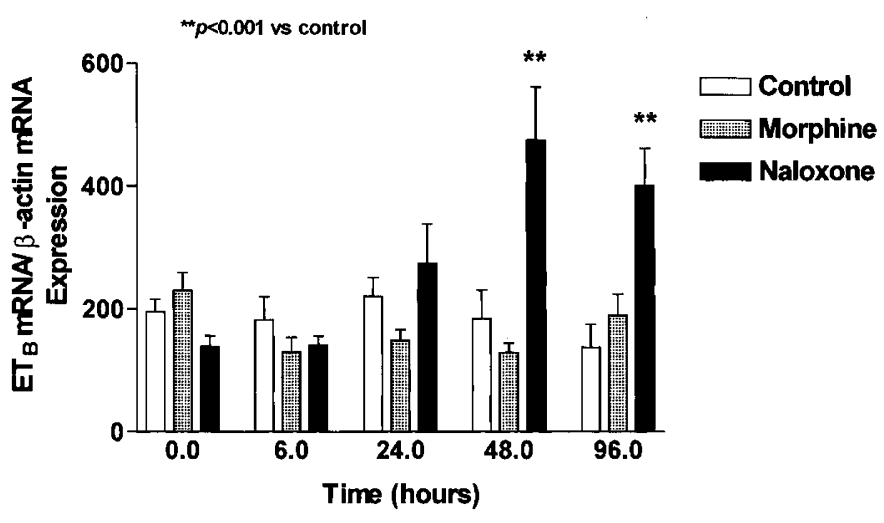

Figure 4. Response of $\mathrm{ET}_{\mathrm{B}}$ receptor to morphine and naloxone in newborn piglet brain vascular endothelial cells. The graph represents the mean ratio \pm SEM of each $\mathrm{ET}_{\mathrm{B}}$ mRNA to $\beta$-actin mRNA expression. Samples from six flasks in each group were analyzed.

demonstrates that morphine increases $\mathrm{ET}_{\mathrm{A}}$ and decreases $\mathrm{ET}_{\mathrm{B}}$ mRNA in newborn piglet brain vascular endothelial cells, whereas an opposite effect is noted with naloxone.

\section{DISCUSSION}

Although no significant change in ET-1, big ET-1, $\mathrm{ET}_{\mathrm{A}}$ mRNA, or $\mathrm{ET}_{\mathrm{B}}$ mRNA were noted with saline-exposed controls of brain vascular endothelial cells, the first test of our hypothesis is demonstrated by the effects of morphine on ET-1 production in the media. Morphine exposure led to increased levels of ET-1 at 6 and 48 h, decreased levels of big ET-1 at $48 \mathrm{~h}$, and increased $\mathrm{ET}_{\mathrm{A}}$ receptor mRNA at 6, 24, 48, and $96 \mathrm{~h}$, with no appreciative effect on $\mathrm{ET}_{\mathrm{B}}$ receptor mRNA expression. These responses of brain vascular endothelial cells to morphine exposure would be expected to lead to vasoconstriction of cerebral vasculature in vivo $(3,6,13,14)$ as well as to have a mitogenic effect on vascular smooth muscle $(11,13-15)$. Other investigators have noted hypotensive effects of opioids, possibly due to stimulation of $\mathrm{NO}$ release by $\mathrm{Mu}-3$ receptor activation (16). This opioid-induced vasodilation in newborn piglets has been found to be partially restored after blockade of ET-1 receptors (6). A recent study by $\mathrm{Hu}$ et al. (17) demonstrated that morphine induces apoptosis in primary human fetal microglial and neuronal cell cultures, an effect that was blocked by naloxone. Thus, the present findings are consonant with previous studies. Elevation of ET-1 levels with reduction of big ET-1 levels may indicate increased activity of ECE, as opposed to increased production of ET precursors (prepro ET or big ET) (18). Morphine has been shown to increase activity of angiotensin converting enzyme (ACE), presumably by interactions within the nucleus of endothelial cells and not mediated by opioid receptors (18). Effects of morphine on ET receptor expression leading to changes in ET and/or big ET levels via feedback mechanisms is also possible $(19,20)$, although less likely given the effects on $\mathrm{ET}_{\mathrm{A}}$ and $\mathrm{ET}_{\mathrm{B}}$ receptor mRNA expression.

The second test of our hypothesis that naloxone exposure would result in responses opposite to that of morphine is demonstrated in Figures 1 through 5. Naloxone exposure led to significantly decreased levels of ET-1 at 6, 48, and $96 \mathrm{~h}$; increased levels of big ET-1 at 24, 48, and 96 h; decreased ET $_{\mathrm{A}}$ receptor mRNA at 6,48 , and $96 \mathrm{~h}$; and increased $\mathrm{ET}_{\mathrm{B}}$ receptor mRNA at 48 and $96 \mathrm{~h}$. Interestingly, these effects of naloxone on the piglet brain vascular endothelial cells were the result of primary exposure to naloxone, rather than the result of naloxone rescue of cells previously exposed to morphine. Naloxone is a competitive antagonist of opioids thought to have essentially no pharmacologic activity in the absence of administered or endogenous opioid agonists $(21,22)$. Our findings of essentially opposite effects of naloxone on endothelin-related responses compared with morphine suggest the effects of morphine on ET-1 and its receptors are mediated by opiate receptors potentially blocked by naloxone. Activity of naloxone in the absence of prior exposure of the cell culture to morphine implies the presence of endogenous opioids in the piglet brain vascular endothelial cells. Our findings that opioid receptor antagonism increased levels of big ET-1 while decreasing levels of ET-1 again lend evidence to the existence of opioid receptors with influence upon ECE activity. The dose of morphine used in the present study was based on pharmacokinetic studies using single morphine doses of $0.1 \mathrm{mg} / \mathrm{kg}$ in preterm infants (23) and loading doses of $0.1 \mathrm{mg} / \mathrm{kg} / \mathrm{h}$ for $2 \mathrm{~h}$, followed by infusion doses (24), which demonstrated serum levels of $100 \mathrm{ng} / \mathrm{mL}$ or greater. One limitation of the study is that we did not measure the levels of morphine or its metabolites in the media. Furthermore, pretreatment of the cells with naloxone, followed by morphine exposure would have offered other possible explanations to our findings.

\section{CONCLUSIONS}

In summary, morphine and naloxone exposure of cultured newborn piglet brain vascular endothelial cells led to changes in levels of ET-1 and expression of its receptors. The changes noted would be expected to induce brain vascular constriction and changes in cerebral blood pressure and blood flow. In preterm infants such changes in cerebral blood flow could be a risk factor for development of IVH (25) or PVL (26), important morbidities in the preterm newborn population. Recent findings of the Neopain Multicenter Trial Group demonstrated that the combination of death, IVH, and PVL occurred more frequently in infants of gestational ages between 27 and 29 wk who were treated with $0.1 \mathrm{mg} / \mathrm{kg}$ morphine loading dose followed by infusions of $20 \mu \mathrm{g} / \mathrm{kg} / \mathrm{h}$ (27). Further investigation of the effects of opioid administration on human newborn infants will be necessary to more precisely identify any true risks of such drug administration. Contributions of the various ET receptors to vasoconstriction seem to vary greatly among species, and among anatomic locations within species (12), and effects of morphine may differ in anesthetized versus unanesthetized subjects (28). Also, preterm human infants may be somewhat protected from the vasoactive effects of ET-1 due to lack of development of the muscularis layer in some cerebral arteries (29). Interactions between opioids and ET in vivo are likely very complex, possibly including regulatory mechanisms such as induction of eventual hydrolytic inactivation of ET-1 via endopeptidases by morphine infusion (30). We are currently undertaking a study on human preterm infants at our institution to evaluate effects of opioid administration on levels 


\section{Control}

Lanes
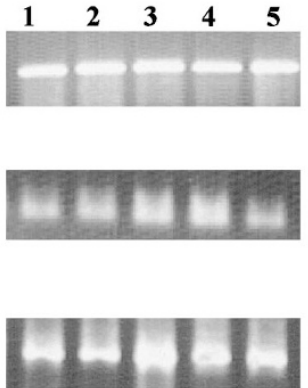

Morphine
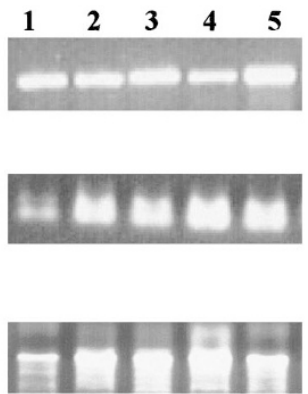

Naloxone

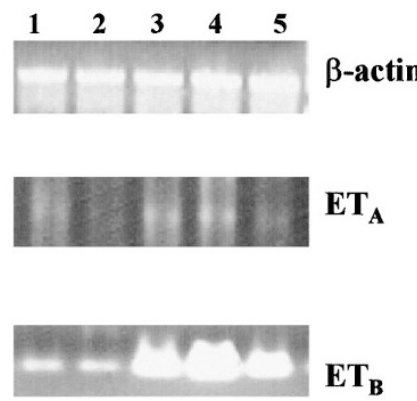

Figure 5. This figure represents gels of a single sample taken from a group of six samples at each time interval, for RT-PCR amplification of newborn piglet brain vascular endothelial cell $\beta$-actin, $\mathrm{ET}_{\mathrm{A}}$, and $\mathrm{ET}_{\mathrm{B}}$ receptor mRNA expression. Lane $1=0 \mathrm{~h}$; lane $2=6 \mathrm{~h}$; lane $3=24 \mathrm{~h}$; lane $4=48 \mathrm{~h}$; and lane $5=$ $96 \mathrm{~h}$ of incubation.

of ET and other vasoactive mediators, in an effort to better understand the possibly harmful effects of a routinely prescribed medication for preterm infants.

\section{REFERENCES}

1. Modanlou HD, Beharry KD 1998 Biochemical and molecular endothelin responses to morphine sulfate infusion in conscious newborn piglets. Can J Physiol Pharmacol $76: 443-450$

2. Thorin E, Nguyen TD, Bouthillier A 1998 Control of vascular tone by endogenous endothelin-1 in human pial arteries. Stroke 29:175-180

3. Gorlach C, Benyo Z, Wahl M 1998 Endothelin-1-induced contraction in cerebral vessels mediated by phospholipase C/protein kinase C cascade. Kidney Int Supp $54:$ S224-S225

4. Gilbert P, Tremblay J, Thorin E 2001 Endothelium-derived endothelin-1 reduces cerebral artery sensitivity to nitric oxide by a protein kinase $\mathrm{C}$-independent pathway. Stroke 32:2351-2355

5. Barg J, Belcheva MM, Zimlichman R, Levy R, Saya D, McHale RJ, Johnson FE, Coscia CJ, Vogel Z 1994 Opioids inhibit endothelin-mediated DNA synthesis, phosphoinositide turnover, and $\mathrm{Ca}^{2+}$ mobilization in rat $\mathrm{C} 6$ glioma cells. J Neurosci $14: 5858-5864$

6. Kasemsri T, Armstead WM 1997 Endothelin production links superoxide generation to altered opioid-induced pial artery vasodilation after brain injury in pigs. Stroke 28:190-197

7. Schilling L, Feger GI, Ehrenreich H, Wahl M 1995 Endothelin-3-induced relaxation of isolated rat basilar artery is mediated by an endothelial $\mathrm{ET}_{\mathrm{B}}$-type endothelin receptor. J Cereb Blood Flow Metab 15:699-705

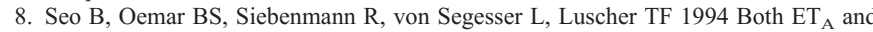
$\mathrm{ET}_{\mathrm{B}}$ receptors mediate contraction to endothelin-1 in human blood vessels. Circulation 89:1203-1208

9. Clozel M, Gray GA, Breu V, Loffler BM, Osterwalder R 1995 The endothelin ET $_{\mathrm{B}}$ receptor mediates both vasodilation and vasoconstriction in vivo. Biochem Biophys Res Commun 186:867-873

10. Kimura S, Kasuya Y, Sawamura T, Shinmi O, Sugita Y, Yanagisawa M, Goto K, Masaki T 1988 Structure-activity relationships of endothelin: importance of the C-terminal moiety. Biochem Biophys Res Commun 156:1182-1186

11. Stjernquist M 1998 Endothelins - vasoactive peptides and growth factors. Cell Tissue Res 292:1-9

12. Yanagisawa M 1994 The endothelin system-a new target for therapeutic intervention Circulation 89:1320-1322

13. Schiffrin EL, Lariviere R, Li JS, Sventek P, Touyz RM 1995 Enhanced expression of endothelin-1 gene may cause blood pressure-independent vascular hypertrophy. J Cardiovasc Pharmacol 26:55-58
14. Chi OZ, Lee DI Liu X, Weiss HR 2000 The effects of morphine on blood-brain barrier disruption caused by intracarotid injection of hyperosmolar mannitol in rats. Anesth Analg 90:603-608

15. Goldie RG 1999 Endothelins in health and disease: an overview. Clin Exp Pharmacol Physiol 26:145-148

16. Stephano GB, Hartman A, Bilfinger TV, Maghazine HI, Lui Y, Casares F, Goligorsky MS 1995 Presence of the mu-3 opiate receptor in endothelial cells. Coupling to nitric oxide production and vasodilation. J Biol Chem 270:30290-30293

17. Hu S, Sheng WS, Lokensgard JR, Peterson PK 2002 Morphine induces apoptosis of human microglia and neurons. Neuropharmacology 42:829-836

18. Melzig MF, Heder G, Siems WE, Zipper J 1998 Stimulation of endothelial angiotensin-converting enzyme by morphine via non-opioid receptor mediated processes. Pharmazie 53:634-637

19. Hayes WG, Ferro CJ, O'Kane KP, Somerville D, Lomax CC, Webb DJ 1996 Systemic endothelin receptor blockade decreases peripheral vascular resistance and blood pressure in humans. Circulation 93:1860-1870

20. Shigeno T, Clozel M, Sakai S, Saito A, Goto K 1995 The effect of Bosentan, a new potent endothelin receptor antagonist, on the pathogenesis of cerebral vasospasm. Neurosurgery 37:87-91

21. Medical Economics Staff 2002 Physician's Desk Reference. Medical Economics Company, New Jersey, p 1322

22. Hardman JG, Limbird LE (eds) 2001 Goodman and Gilman's The Pharmacologic Basis of Therapeutics, 10th Ed. McGraw Hill, New York, p 602

23. Bhat R, Chari G, Gulati A, Aldana O, Velamati R, Bhargava H 1990 Pharmacokinetics of a single dose of morphine in preterm infants during the first week of life. J Pediatr 117:477-481

24. Hartley R, Green M, Quinn M, Levene MI 1993 Pharmacokinetics of morphine infusion in premature neonates. Arch Dis Child 69:55-58

25. Roland EH, Hill A 1997 Intraventricular hemorrhage and posthemorrhagic hydrocephalus. Clin Perinatol 24:589-604

26. Volpe JJ 2001 Neurobiology of periventricular leukomalacia in the preterm infant. Pediatr Res 50:553-562

27. NEOPAIN Multicenter Group 2002 Effects of morphine therapy on neurologic outcomes in ventilated preterm neonates: primary outcomes from the NEOPAIN (Neurologic Outcomes \& Pre-emptive Analgesia in Neonates) Multicenter Trial. Pediatr Res 51(suppl 4):361A(abstr)

28. Kayaalp SO, Kaymakcalan SA 1966 A comparative study of the effects of morphine in unanaesthetized and anaesthetized cats. Br J Pharmacol 26:196-204

29. Kuban KCK, Gilles FH 1985 Human telencephalic angiogenesis. Ann Neurol 17:539-548

30. Wang TL, Chang H 2001 Intravenous morphine reduces plasma endothelin-1 concentration through activation of neutral endopeptidase 24.11 in patients with myocardial infarction. Ann Emerg Med 37:445-449 